Marquette University

e-Publications@Marquette

Finance Faculty Research and Publications

Finance, Department of

$12-1-2012$

\title{
Convenience in the mutual fund industry
}

George D. Cashman

Marquette University, george.cashman@marquette.edu

Accepted version. Journal of Corporate Finance, Vol. 18, No. 5 (December 2012): 1326-1336. DOI. (C) 2012 Elsevier B.V. Used with permission.

George D. Cashman was affiliated with Texas Tech University at the time of publication. 


\section{e-Publications@Marquette}

\section{Finance Faculty Research and Publications/Department of Finance}

This paper is NOT THE PUBLISHED VERSION; but the author's final, peer-reviewed manuscript. The published version may be accessed by following the link in the citation below.

Journal of Corporate Finance, Vol. 18, No. 5 (2012): 1326-1336. DOI. This article is (C) Elsevier and permission has been granted for this version to appear in e-Publications@Marquette. Elsevier does not grant permission for this article to be further copied/distributed or hosted elsewhere without the express permission from Elsevier.

\section{Convenience in the Mutual Fund Industry}

\section{George Cashman}

Department of Finance, Marquette University, Milwaukee WI

\section{Abstract}

I examine the role of convenience in the mutual fund industry. I find that investors pay more for relatively convenient funds, and that the flows to convenient funds are less responsive to performance. These findings suggest that investors do not evaluate mutual funds independently, but rather that investors select a primary fund, likely based on beliefs about managerial ability, and then select funds which are relatively convenient to this primary fund.

\section{JEL classification}

G11, G23, L1, L14

Keywords

Mutual funds, Sub-advising, Performance-flow relation

\section{Introduction}

When individuals invest in an actively managed mutual fund, they are primarily purchasing portfolio management (Baumol et al., 1990). Coles et al. (2000), Deli (2002), Cashman (2010) and Warner and Wu (2011) present evidence of the important role that portfolio management ability plays in the 
mutual fund industry. These papers find that a fund manager's marginal compensation is a function of the return investors expect the manager to earn on the next dollar invested with the fund.

Additionally, Berk and Green (2004) assume that investors select funds based on performance, because performance signals portfolio management ability.

Given the importance of portfolio management, fund families generally manage the portfolio of their own funds. However, because flows to the family increase with the number of strategies the family offers, many families include funds following strategies outside their core expertise. Cashman and Deli (2009) find that families will often hire an external third party, a sub-advisor, to manage the portfolio of these divergent funds. While Cashman and Deli (2009) find evidence that sub-advising increases the fund's return over what could be expected if the family managed the portfolio itself, sub-advised funds generally perform worse than comparable family-advised funds. Since sub-advised funds tend to underperform, suggesting they offer inferior portfolio management, why do individuals choose to invest in them?

One possible explanation for selecting a sub-advised fund is that they may be cheaper, offsetting their relatively inferior portfolio management. However, this is not the case. I find that instead of paying less for portfolio management, investors in sub-advised funds pay a significant premium. Specifically, the average price of portfolio management is $7-13 \%$ higher at a sub-advised fund than a family-advised fund. This means that investors paid an additional $\$ 42$ to $\$ 74$ million for portfolio management at subadvised funds. However, this likely understates the true cost of investing in sub-advised funds, as it ignores their relative underperformance. Additionally, I examine families that manage the portfolio of their own funds and also serve as sub-advisors for other families. I find that when the family serves as a sub-advisor, the price of portfolio management is $30 \%$ higher than when the family manages its own funds.

The finding that investors are willing to pay a significant premium at sub-advised funds, especially when they could receive the same portfolio management by investing in an additional family directly, suggests that sub-advised funds must offer some additional benefit to investors. I argue this benefit is convenience. ${ }^{1}$ By investing in a sub-advised fund, investors are able to invest in a strategy different from the family's core expertise, while staying within the family. This is potentially valuable as investors are often advised to limit themselves to a single family "to make life simple" (Fredman and Wiler, 1998, p.268). Investment professionals espouse the convenience of a single family portfolio: the opening of a single account, having a single source for information regarding their entire investment portfolio, and receiving consolidated statements and tax forms. $\stackrel{2}{-}$ Additionally, the mutual fund family has been called "one of the great financial conveniences of our time" (Schifrin, 1994, p.234).

I argue that investors are willing to pay a premium for sub-advised funds because of the convenience they offer. I next examine whether convenience influences fund selection If sub-advised funds are able to charge a premium because they are convenient, then it suggests that investors select sub-advised funds for convenience while they select family-managed funds for portfolio management. If this is the case then I expect flow to sub-advised funds to be less responsive to prior performance, as Berk and Green (2004) assume that investors use prior returns as a signal of portfolio management ability. Consistent with this, I find that while flows to family-advised funds are highly sensitive to high performance, the flows to sub-advised funds are relatively indifferent to performance. Specifically, I find that the flows to sub-advised funds are only $24-36 \%$ as sensitive to high performance as the flows 
to family-advised funds. This is consistent with sub-advised funds being selected for their convenience and not portfolio management ability.

If sub-advised funds are selected because of convenience it suggests that investors do not select funds independently. Likely, investors select a primary fund, or funds, possibly well performing funds in a preferred style, and then select funds in other styles that are convenient to the primary funds. $\frac{3}{-}$ This tendency is potentially harmful to investors, as it increases the risk of their total investment portfolio, while decreasing its expected return. As Elton et al. (2007) find that by limiting oneself to the funds offered by a single family, the risk of the investor's total investment portfolio is higher than if the investor selects funds from a variety of families. Additionally, Siggelkow (2003) finds that funds in families that specialize, offering a limited number of investment strategies, outperform comparable funds in families that offer a multitude of strategies. Therefore, by opening accounts in multiple families, investors are able to reduce the risk of their total portfolio, while selecting better performing funds..$\underline{4}$

Section 2 provides a review of the literature. The data and univariate analyses are reported in Section 3 , while Section 4 contains my examination of the price investors pay for portfolio management. Section 5 explores alternative explanations for the sub-advised premium documented in Section 4 . Section 6 examines the impact of convenience on the performance flow relation. Section 7 concludes.

\section{Related literature}

\section{The decision to hire a sub-advisor}

Massa (2003), Siggelkow (2003), Nanda et al. (2004), Khorana and Servaes (2004), Gallaher et al. (2006) all find that the more investment strategies a fund family offers, the larger the inflow to the family. As the family's revenue is a function of the assets it manages, it is apparent why a family would want to offer multiple strategies. One way for a family to offer a dissimilar strategy is by hiring a sub-advisor.

In Cashman and Deli's (2009) examination of the decision to hire a sub-advisor, they note that a family is more likely to hire a sub-advisor to manage funds following investment strategies outside the family's core expertise. Additionally, Cashman and Deli (2009) find that sub-advised funds underperform comparable family-advised funds, but that the hiring of a sub-advisor improves fund performance over what the family could expect if it had decided to manage the fund internally.

Chen et al. (2011) examine a broader definition of sub-advising, which they refer to as outsourcing. Similar to Cashman and Deli (2009), they find that families are more likely to outsource funds that follow an investment strategy different from the majority of the family's other funds and that these outsourced funds tend to underperform.

\section{The advisory contract}

This paper examines the price that investors pay for portfolio management, which is a function of the advisory contract. While this is not the first paper to examine the advisory contract, prior studies generally view the advisory contracts as determining the advisor's compensation for managing the 
portfolio. Here I view the advisory contract as determining the price the investor pays for portfolio management. $\underline{6}$

Coles et al. (2000) examine the relation between the closed-end fund premium and advisor compensation. They find that the premium is positively related to the level of the advisor's compensation, and that the advisor's marginal compensation is a function of the advisor's marginal product. Deli (2002) examines the advisor's marginal compensation for both open- and closed-ended funds and also finds that the advisor's marginal compensation is a function of the advisor's marginal product.

While Coles et al. (2000) and Deli (2002) find evidence that an advisor's marginal compensation rate is a function of his marginal product, Cashman (2010) and Warner and Wu (2011) find that changes in the marginal compensation rate are a function of changes in the advisor's marginal product. Cashman

(2010) further finds that funds that are likely to see the marginal product of their advisor decline as the fund grows design the advisory contract so that the advisor's marginal compensation also falls as the fund grows. Cashman (2010) asserts that these declining-rate advisory contracts are used to keep marginal compensation in-line with an advisor's decreasing marginal product.

Warner and $\mathrm{Wu}$ (2011) examine changes in the marginal compensation levels. They argue that past performance is a measure of an advisor's marginal product and that following superior performance, marginal compensation rates increase.

These papers all present evidence that the marginal compensation rate is a function of the advisor's marginal product. While this is consistent with economic intuition, it potentially ignores the role played by convenience.

\section{Data and univariate analysis}

\section{Sample selection}

The data come primarily from investment companies' semiannual form N-SAR filings with the U.S. Securities and Exchange Commission (SEC) - specifically, the second N-SAR filing (N-SARB), which corresponds to a fund's fiscal year-end. I collect N-SARBs for all open-end actively managed domestic equity funds filed in 2002 . These filings provide the identity of a fund's advisor, sub-advisor, family, fiscal year-end size, average size over the period covered, turnover (the lesser of purchases and sales divided by average net asset value), whether the fund offers multiple share classes, whether the fund charges a front- or back-end load, the minimum investment amount required to open an account, and the fund's stated investment strategy. In addition to these portfolio characteristics, the N-SAR also provides advisory contract details.

The majority of the sample (67\%) use single-rate advisory contracts; for these funds, the N-SAR provides only the advisory rate specified in the contract. The remaining funds use a declining-rate advisory contract, which specifies the advisory rate as a declining piecewise linear function of fund size. For funds with this type of contract, the N-SAR provides the advisory rates and the corresponding size breakpoints. Additionally, the N-SAR supplies information regarding the number of services, beyond portfolio management, required by the contract and the actual dollar amount that investors paid for portfolio management over the prior 12 months. $\underline{7}$ 
Following Cashman and Deli (2009), I do not consider a fund to be sub-advised if the sub-advisor is owned by the advisor, or if both share a common owner. I collect each advisor's and sub-advisor's Form ADV filing with the SEC and use these to ensure that the sub-advisor is not owned by the advisor and that the two do not share a common owner. Unfortunately, the SEC does not maintain historical ADV filings; therefore, like Cashman and Deli (2009) I am unable to compile a panel. $\underline{8}$

I use sub-advised funds to identify funds that follow strategies different from the majority of the funds in the family and ones that generally under-perform, which makes it unlikely that investors select these funds because of their performance. Therefore, while I focus on sub-advised funds, the results are generalizable beyond sub-advised funds, and the study is not dependent on investors realizing that the fund is sub-advised.

The final sample is composed of all actively managed equity funds that report all of the items listed above. Table 1, Panel A provides a description of the sample. I find that $14 \%$ of the funds in the sample are sub-advised, similar to the $16 \%$ reported in Cashman and Deli (2009) for this period. 9 Panel $\mathrm{B}$ provides descriptive statistics regarding fund characteristics, which are consistent with those reported in Cashman (2010).

Table 1. Sample description. The data are from the SEC's Electronic Data Gathering and Retrieval (EDGAR) Web site. The source is the investment company Form N-SARB and advisor and sub-advisor Form ADV. I collect all NSARBs pertaining to actively managed equity funds filed in calendar year 2002. The N-SAR filing provides me with the fund's size, family affiliation (if applicable), and turnover (the lesser of purchases or sales divided by average net asset value). Additionally the N-SAR provides details regarding the services required of the advisor. The N-SAR filing asks specifically if 15 different services are required; the service variable is the number of these services that are provided, as such, its maximum value is 15 . The 15 services that N-SAR asks about are (1) the occupancy and office rental, (2) clerical and bookkeeping services, (3) accounting services, (4) services of independent audits, (5) services of outside counsel, (6) registration and filing fees, (7) stationery, supplies, and printing, (8) salaries and compensation of interested directors, (9) salaries and compensation of disinterested directors, (10) salaries and compensation of officers who are not directors, (11) reports to shareholders, (12) determination of offering and redemption prices, (13) trading department, (14) prospectus preparation and printing, and (15) other. Lastly, the N-SAR provides details about whether the fund employs a sub-advisor. If a fund employees a sub-advisor, I use the ADV filings to compare the ownership of the advisor and sub-advisor. If the advisor owns a $20 \%$ or greater stake in the sub-advisor, of if a third party owns a $20 \%$ stake in both the advisor and sub-advisor, I do not classify this as a sub-advised fund.

\section{Panel A: Sample composition}

\section{Fund type}

Total sample

Family-managed fund with declining rate advisory contracts

Sub-advised fund with declining rate advisory contracts

\section{Number \% of Sample}

1573

$1346 \quad 86$

$420 \quad 31$

$227 \quad 14$

$92 \quad 41$ 
Panel B: Descriptive statistics for turnover, fund and family size, and the number of services required by the advisory contract

\section{Mean Median Maximum 75th Percentile 25th Percentile Minimum}

$\begin{array}{lllllll}\text { Turnover } & 97 & 62 & 6593 & 112 & 31 & 0 \\ \text { Fund size (\$million) } & 738 & 104 & 99,162 & 382 & 22 & 1 \\ \text { Family size (\$billion) } & 38 & 8 & 554 & 52 & 1 & 0.1 \\ \text { Services } & 5.5 & 6 & 15 & 7 & 4 & 0\end{array}$

\section{Univariate analysis: the price of portfolio management}

Panel A of Table 2 presents descriptive statistics regarding the price of portfolio management. The price that investors pay for portfolio management is a function of the advisory contract and fund size. Therefore, I use four different price measures to account for different aspects of the price of portfolio management. The first measure is the maximum rate; this is the highest advisory rate specified in the contract and reflects the most that an investor would pay to have a dollar in the fund managed. The second measure is the marginal rate, which is the advisory rate that corresponds to the fund's current size and represents what an investor must pay to have an additional dollar managed. $\underline{10}$ Third is the contract rate, which is calculated by applying the contract's advisory rate to the fund's fiscal year-end size and then dividing by the fund's fiscal year-end size. This measures what an investor pays on average to have a dollar in the fund managed. The fourth measure is the actual rate and is calculated by dividing the actual dollar amount that investors paid for portfolio management over the prior 12 months, by the average fund size reported in the N-SAR. $\underline{11}$ The actual rate reflects what investors actually paid to have a dollar invested with the fund managed and accounts for any fee-waiving the fund may have engaged in over the year.

Table 2. Univariate analysis. The sample is composed of 1573 actively managed equity funds with an N-SAR filing in calendar year 2002, which I was able to match to the corresponding ADV filing. Panel A presents descriptive statistics. Panel B presents the comparisons of the averages. The Marginal Rate is the advisory rate applicable given the fund's current size. The Contract Rate is calculated by applying the advisory contract to the fund's reported year-end size and dividing this by the fund's year-end size. The Actual Rate is the dollar amount investors paid for portfolio management divided by the average fund size reported on the N-SAR. $* * *, * *, *$ indicate significance at $1 \%, 5 \%$, and $10 \%$ respectively.

\section{Panel A: Descriptive statistics for maximum rate, marginal rate, contract rate, actual rate, average drop, and range}

Obs. Mean Median Maximum 75th Percentile 25th Percentile Minimum

Whole sample

\begin{tabular}{|c|c|c|c|c|c|c|c|}
\hline Maximum rate (\%) & 1573 & 0.780 & 0.750 & 4.880 & 1.000 & 0.650 & 0.030 \\
\hline Marginal rate (\%) & 1573 & 0.760 & 0.750 & 4.880 & 0.950 & 0.600 & 0.030 \\
\hline Contract rate (\%) & 1573 & 0.767 & 0.750 & 4.880 & 0.950 & 0.616 & 0.030 \\
\hline Actual rate (\%) & 1540 & 0.789 & 0.782 & 4.671 & 0.976 & 0.585 & 0.011 \\
\hline \multicolumn{8}{|l|}{ Family-managed } \\
\hline Maximum rate (\%) & 1346 & 0.772 & 0.750 & 4.880 & 1.000 & 0.650 & 0.030 \\
\hline
\end{tabular}


Panel A: Descriptive statistics for maximum rate, marginal rate, contract rate, actual rate, average drop, and range

Obs. Mean Median Maximum 75th Percentile 25th Percentile Minimum

$\begin{array}{llllllll}\text { Marginal rate (\%) } & 1346 & 0.751 & 0.750 & 4.880 & 0.950 & 0.600 & 0.030 \\ \text { Contract Rate (\%) } & 1346 & 0.758 & 0.750 & 4.880 & 0.950 & 0.600 & 0.030 \\ \text { Actual rate (\%) } & 1314 & 0.777 & 0.775 & 4.671 & 0.957 & 0.571 & 0.010 \\ \text { Sub-advised } & & & & & & & \\ \text { Maximum rate (\%) } & 227 & 0.829 & 0.850 & 1.950 & 0.950 & 0.700 & 0.250 \\ \text { Marginal rate (\%) } & 227 & 0.816 & 0.850 & 1.950 & 0.950 & 0.700 & 0.250 \\ \text { Contract rate (\%) } & 227 & 0.822 & 0.850 & 1.950 & 0.950 & 0.700 & 0.250 \\ \text { Actual rate (\%) } & 226 & 0.855 & 0.882 & 2.163 & 1.028 & 0.680 & 0.143\end{array}$

Panel B: Mean and median comparison Mean

\section{Family-}

advised

\begin{abstract}
Max rate (\%)
\end{abstract}
0.772

Marginal rate

(\%)

0.751

Contract rate

(\%)
0.758

0.777

Actual rate (\%)

\section{Sub-} advised

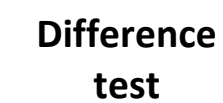

0.829

0.816

0.822

0.855
$-3.50 * * *$

$-3.90 * * *$

$-3.89 * * *$

$-3.36 * * *$

\section{Family- advised}

\section{Median}

Subadvised

0.750

0.850

0.850

$-5.16^{* * *}$

0.750

0.750

0.775

0.850

$-5.02 * * *$
0.777

Panel B presents the univariate analysis of the price of portfolio management. I find evidence suggesting that investors pay significantly more for a sub-advised fund than a family-advised fund. The mean maximum, marginal, contract, and actual rates are $7 \%, 9 \%, 8 \%$, and $10 \%$, higher for sub-advised funds than family-advised funds, respectively. Comparing the medians shows that the maximum and contract rates are both $13 \%$ higher for sub-advised funds, while the actual rate is $14 \%$ higher. To provide an impression of the economic significance of this difference, I multiply the sub-advised fund premium by the total amount of assets managed by sub-advised funds. Using the difference in the means, I estimate that in 2002 alone investors paid an additional \$42 to \$58 million (\$74-79 million at the median) for portfolio management at sub-advised funds, while accepting their relative underperformance. The results suggest that investors receive some benefit from sub-advised funds other than portfolio management; I argue this benefit is convenience.

\section{The price of portfolio management}

I now examine the price of portfolio management in a multivariate setting. I control for the same fund characteristics that Coles et al. (2000), Deli (2002), and Cashman (2010) control for in their examinations of the advisory contract. Specifically, I include indicator variables for aggressive investment strategy (namely aggressive capital appreciation or growth), multiple share classes, and the presence of front or back load. Additionally, I control for the minimum amount required to open an account with the fund, turnover, fund size, family size (if applicable), and the number of services, 


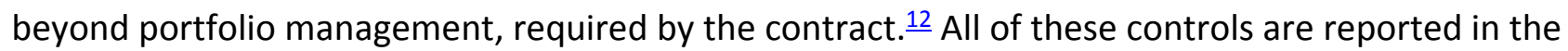
fund's N-SAR filing.

I also control for the type of advisory contract used by the fund. While Cashman (2010) finds no evidence of a difference in the maximum rate specified by single- and declining-rate advisory contracts, he does find that the marginal rate is significantly lower for declining-rate advisory contracts. Finally, to control for potential large family effects, specifically intra-family trading and search costs, I include the number of funds in the family. ${ }^{13}$ Massa (2003) argues that the value of intra-family trading increases with the number of funds in the family. Additionally, being part of a large family could reduce the search costs associated with finding a fund. Both of which could allow funds in larger families to charge more than funds in smaller families. Table 3 presents the results of this analysis.

Table 3. The price of portfolio management. The sample is composed of 1573 actively managed equity funds with an N-SAR filing in calendar year 2002, which I was able to match to the corresponding ADV filing. The Maximum Rate is the highest (first) advisory rate specified in the advisory contract. The Marginal Rate is the advisory rate applicable given the fund's current size. The Contract Rate is calculated by applying the advisory contract to the fund's reported year-end size and dividing this by the fund's year-end size. The Actual Rate is the dollar amount investors paid for portfolio management divided by the average fund size reported on the N-SAR. Sub-Advised is an indicator variable set to one if the fund is managed by a sub-advisor and zero if the fund is run by its family. Aggressive is an indicator variable that takes the value of one if the fund follows an aggressive investment strategy, aggressive growth or aggressive capital appreciation and zero otherwise. DRAC is an indicator variable that takes the value of one if the advisory contract specifies a declining advisory rate and is zero otherwise. Family Funds is the number of funds in the family. Multi Class is an indicator variable that takes the value of one if the fund offers multiple classes of shares and the value of zero if the fund only has one share class. Front Load is an indicator variable that takes the value of one if the fund has a front-end load and zero otherwise. Back Load is an indicator variable that takes the value of one if the fund has a redemption fee or contingent deferred sales charge and zero otherwise. As Multi Class will be perfectly correlated with Front Load and Back Load, I orthogonalize both with respect to Multi Class. Ln (Min Invest) is the natural log of the minimum investment that the fund requires to open an account for an investor. Turn is the lesser of the fund's purchases and sales divided by average net assets. $\operatorname{Ln}($ Size $)$ is the natural log of the fund's total net assets. $L n$ (Family Size) is the natural log of all assets controlled by the fund's family. Services is the number of services required by the advisory contract. $* * *, * *, *$ indicate significance at $1 \%, 5 \%$, and $10 \%$ respectively.

\section{Maximum rate Marginal rate Contract rate Actual rate}

$\begin{array}{lllll}\text { Intercept } & 1.139 * * * & 1.217^{* * *} & 1.216^{* * *} & 1.078^{* * *} \\ & (21.46) & (22.72) & (22.70) & (14.42) \\ \text { Sub-advised } & 0.056^{* * *} & 0.067^{* * *} & 0.064^{* * *} & 0.081^{* * *} \\ & (3.02) & (3.60) & (3.45) & (3.17) \\ \text { Aggressive } & 0.032^{* *} & 0.034^{* *} & 0.033^{* *} & 0.021 \\ & (2.41) & (2.48) & (2.44) & (1.15) \\ \text { DRAC } & -0.026^{*} & -0.078^{* * *} & -0.059 * * * & -0.063^{* * *} \\ & (-1.82) & (-5.44) & (-4.10) & (-3.16) \\ \text { Family funds } & 0.003^{* * *} & 0.002 * * * & 0.003^{* * *} & 0.003^{* * *} \\ & (3.26) & (2.99) & (3.14) & (2.66) \\ \text { Multi class } & 0.016 & 0.015 & 0.015 & 0.019\end{array}$




\section{Maximum rate Marginal rate Contract rate Actual rate}

\begin{tabular}{|c|c|c|c|c|}
\hline & $(1.12)$ & (1.03) & (0.99) & $(0.91)$ \\
\hline \multirow{2}{*}{ Front load } & -0.032 & -0.033 & -0.033 & $-0.092 * *$ \\
\hline & $(-1.06)$ & $(-1.10)$ & $(-1.09)$ & $(-2.24)$ \\
\hline \multirow{2}{*}{ Back load } & $0.106 * * *$ & $0.119 * * *$ & $0.117 * * *$ & $0.164 * * *$ \\
\hline & (3.52) & (3.89) & (3.83) & (3.92) \\
\hline \multirow{2}{*}{$\operatorname{Ln}(\min$ invest) } & $0.007 * * *$ & $0.008 * * *$ & $0.007 * * *$ & $0.011 * * *$ \\
\hline & (3.91) & (3.95) & (3.90) & $(4.31)$ \\
\hline \multirow{2}{*}{ Turn $\left(* 10^{-3}\right)$} & $0.526 * * *$ & $0.529 * * *$ & $0.531^{* * *}$ & $1.059 * * *$ \\
\hline & (17.51) & (17.47) & (17.52) & $(16.16)$ \\
\hline \multirow{2}{*}{$\operatorname{Ln}($ size) } & 0.002 & $-0.008^{* *}$ & $-0.007^{*}$ & $0.017^{* * *}$ \\
\hline & $(0.52)$ & $(-2.06)$ & $(-1.75)$ & $(3.16)$ \\
\hline \multirow{2}{*}{ Ln(family) } & $-0.039 * * *$ & $-0.036 * * *$ & $-0.037 * * *$ & $-0.050 * * *$ \\
\hline & $(-10.62)$ & $(-9.85)$ & $(-10.08)$ & $(-9.73)$ \\
\hline \multirow{2}{*}{ Services } & $0.013^{* * *}$ & $0.013^{* * *}$ & $0.013^{* * *}$ & $0.014^{* * *}$ \\
\hline & (6.77) & (6.28) & (6.29) & $(5.16)$ \\
\hline Obs & 1573 & 1573 & 1573 & 1540 \\
\hline $\operatorname{Adj}-R^{2}$ & 0.3053 & 0.3306 & 0.3241 & 0.2557 \\
\hline
\end{tabular}

I find that regardless of the price proxy examined, sub-advised funds charge significantly more than family-advised funds, which is consistent with the univariate analysis. $\frac{14}{1}$ Specifically, the maximum rate charged by a sub-advised fund is $7 \%$ higher than that of a family-advised fund while the marginal, contract, and actual rates are $9 \%, 8 \%$ and $10 \%$ higher for sub-advised funds, respectively. Again, the fact that investors are willing to pay a premium for sub-advised funds, which generally underperform, suggests that investors are purchasing something other than portfolio management.

To ensure that the price differences observed in Table 3 are not driven by the types of funds typically sub-advised, I reexamine the relation between sub-advising and the price of portfolio management using two different matched sample. In Panel A of Table 4, I match each sub-advised fund to the family-advised fund that is closest in size within the investment strategy. In Panel B, I match each subadvised fund to a family-advised fund based on each fund's estimated probability of being sub-advised. I calculate each fund's probability of being sub-advised using Model 2 of Table 6 from Cashman and Deli (2009) and then match each sub-advised fund to the family-advised funds with the closest estimated probability of being sub-advised. $\underline{15}$

Table 4. Matched sample analysis of the price of portfolio management. The samples are composed of a total of 454funds. The 227 sub-advised funds and 227 family-advised matched funds. In Panel A the family-advised matched funds are selected based on investment style and fund size. In Panel B the family-advised funds are selected based on their probability of being sub-advised, as predicted by Cashman and Deli (2009)Table 6 Model 2. The Maximum Rate is the highest (first) advisory rate specified in the advisory contract. The Marginal Rate is the advisory rate applicable given the fund's current size. The Contract Rate is calculated by applying the advisory contract to the fund's reported year-end size and dividing this by the fund's year-end size. The Actual Rate is the dollar amount investors paid for portfolio management divided by the average fund size reported on 
the N-SAR. Sub-Advised is an indicator variable set to one if the fund is managed by a sub-advisor and zero if the fund is run by its family. Aggressive is an indicator variable that takes the value of one if the fund follows an aggressive investment strategy, aggressive growth or aggressive capital appreciation and zero otherwise. DRAC is an indicator variable that takes the value of one if the advisory contract specifies a declining advisory rate and is zero otherwise. Family Funds is the number of funds in the family. Multi Class is an indicator variable that takes the value of one if the fund offers multiple classes of shares and the value of zero if the fund only has one share class. Front Load is an indicator variable that takes the value of one if the fund has a front-end load and zero otherwise. Back Load is an indicator variable that takes the value of one if the fund has a redemption fee or contingent deferred sales charge and zero otherwise. As Multi Class will be perfectly correlated with Front Load and Back Load, I orthogonalize both with respect to Multi Class. Ln (Min Invest) is the natural log of the minimum investment that the fund requires to open an account for an investor. Turn is the lesser of the fund's purchases and sales divided by average net assets. $\operatorname{Ln}($ Size) is the natural log of the fund's total net assets. $L n$ (Family Size) is the natural log of all assets controlled by the fund's family. Services is the number of services required by the advisory contract. $* * *, * *, *$ indicate significance at $1 \%, 5 \%$, and $10 \%$ respectively.

\section{Maximum rate Marginal rate Contract rate Actual rate}

Panel A. Investment style and size matched sample

\begin{tabular}{|c|c|c|c|c|}
\hline Intercept & $\begin{array}{l}1.121^{* * *} \\
(10.88)\end{array}$ & $\begin{array}{l}1.173^{* * *} \\
(11.38)\end{array}$ & $\begin{array}{l}1.156^{* * *} \\
(11.21)\end{array}$ & $\begin{array}{l}0.883 * * * \\
(5.83)\end{array}$ \\
\hline Sub-advised & $\begin{array}{l}0.069 * * * \\
(2.73)\end{array}$ & $\begin{array}{l}0.079 * * * \\
(3.16)\end{array}$ & $\begin{array}{l}0.072^{* * *} \\
(2.86)\end{array}$ & $\begin{array}{l}0.071 * * \\
(1.96)\end{array}$ \\
\hline Aggressive & $\begin{array}{l}-0.032 \\
(-1.26)\end{array}$ & $\begin{array}{l}-0.031 \\
(-1.23)\end{array}$ & $\begin{array}{l}-0.029 \\
(-1.13)\end{array}$ & $\begin{array}{l}-0.022 \\
(-0.31)\end{array}$ \\
\hline DRAC & $\begin{array}{l}-0.058^{* *} \\
(-2.21)\end{array}$ & $\begin{array}{l}-0.098^{* * *} \\
(-3.74)\end{array}$ & $\begin{array}{l}-0.076 * * * \\
(-2.90)\end{array}$ & $\begin{array}{l}-0.060 \\
(-1.57)\end{array}$ \\
\hline Family funds & $\begin{array}{l}0.005^{* * *} \\
(2.84)\end{array}$ & $\begin{array}{l}0.005^{* * *} \\
(3.05)\end{array}$ & $\begin{array}{l}0.005^{* * *} \\
(2.86)\end{array}$ & $\begin{array}{l}0.007^{* * *} \\
(2.77)\end{array}$ \\
\hline Multi class & $\begin{array}{l}0.001 \\
(0.05)\end{array}$ & $\begin{array}{l}0.001 \\
(0.05)\end{array}$ & $\begin{array}{l}-0.001 \\
(-0.05)\end{array}$ & $\begin{array}{l}0.012 \\
(0.30)\end{array}$ \\
\hline Front load & $\begin{array}{l}0.010 \\
(0.16)\end{array}$ & $\begin{array}{l}0.002 \\
(0.03)\end{array}$ & $\begin{array}{l}0.011 \\
(0.17)\end{array}$ & $\begin{array}{l}-0.006 \\
(-0.07)\end{array}$ \\
\hline Back load & $\begin{array}{l}0.040 \\
(0.62)\end{array}$ & $\begin{array}{l}0.052 \\
(0.82)\end{array}$ & $\begin{array}{l}0.042 \\
(0.66)\end{array}$ & $\begin{array}{l}0.081 \\
(0.88)\end{array}$ \\
\hline $\operatorname{Ln}(\min$ invest) & $\begin{array}{l}0.007^{*} \\
(1.88)\end{array}$ & $\begin{array}{l}0.007 * * \\
(2.07)\end{array}$ & $\begin{array}{l}0.007^{* *} \\
(2.00)\end{array}$ & $\begin{array}{l}0.015^{* * *} \\
(3.04)\end{array}$ \\
\hline Turn $\left(* 10^{-3}\right)$ & $\begin{array}{l}0.292 * * * \\
(3.15)\end{array}$ & $\begin{array}{l}0.266 * * * \\
(2.87)\end{array}$ & $\begin{array}{l}0.286 * * * \\
(3.08)\end{array}$ & $\begin{array}{l}0.464 * * * \\
(3.43)\end{array}$ \\
\hline $\operatorname{Ln}($ size $)$ & $\begin{array}{l}0.008 \\
(0.97)\end{array}$ & $\begin{array}{l}0.001 \\
(0.12)\end{array}$ & $\begin{array}{l}0.003 \\
(0.37)\end{array}$ & $\begin{array}{l}0.044 * * * \\
(3.77)\end{array}$ \\
\hline Ln(family) & $\begin{array}{l}-0.037 * * * \\
(-5.17)\end{array}$ & $\begin{array}{l}-0.036 * * * \\
(-5.03)\end{array}$ & $\begin{array}{l}-0.036 * * * \\
(-5.03)\end{array}$ & $\begin{array}{l}-0.054^{* * *} \\
(-5.26)\end{array}$ \\
\hline ervices & 0.005 & 0.005 & 0.005 & $0.012 * *$ \\
\hline
\end{tabular}




\section{Maximum rate Marginal rate Contract rate Actual rate}

$\begin{array}{lllll} & (1.46) & (1.42) & (1.50) & (2.31) \\ \text { Obs } & 454 & 454 & 454 & 454 \\ \text { Adj-R }{ }^{2} & 0.1132 & 0.1398 & 0.1268 & 0.1073\end{array}$

Panel B. Probability matched sample

\begin{tabular}{|c|c|c|c|c|}
\hline Intercept & $\begin{array}{l}0.820 * * * \\
(11.10)\end{array}$ & $\begin{array}{l}0.851^{* * *} \\
(11.40)\end{array}$ & $\begin{array}{l}0.834^{* * *} \\
(11.20)\end{array}$ & $\begin{array}{l}0.647^{* * *} \\
(6.63)\end{array}$ \\
\hline Sub-advised & $\begin{array}{l}0.086 * * * \\
(5.10)\end{array}$ & $\begin{array}{l}0.084 * * * \\
(4.96)\end{array}$ & $\begin{array}{l}0.086 * * * \\
(5.07)\end{array}$ & $\begin{array}{l}0.106^{* * *} \\
(4.77)\end{array}$ \\
\hline Aggressive & $\begin{array}{l}0.034^{*} \\
(1.86)\end{array}$ & $\begin{array}{l}0.041 * * \\
(2.23)\end{array}$ & $\begin{array}{l}0.037^{* *} \\
(2.06)\end{array}$ & $\begin{array}{l}0.040 * \\
(1.66)\end{array}$ \\
\hline DRAC & $\begin{array}{l}-0.058 * * * \\
(-3.16)\end{array}$ & $\begin{array}{l}-0.087^{* * *} \\
(-4.77)\end{array}$ & $\begin{array}{l}-0.075^{* * *} \\
(-4.11)\end{array}$ & $\begin{array}{l}-0.092^{* * *} \\
(-3.83)\end{array}$ \\
\hline Family funds & $\begin{array}{l}-0.008 \\
(-0.43)\end{array}$ & $\begin{array}{l}-0.013 \\
(-0.71)\end{array}$ & $\begin{array}{l}-0.012 \\
(-0.65)\end{array}$ & $\begin{array}{l}-0.016 \\
(-0.67)\end{array}$ \\
\hline Multi class & $\begin{array}{l}-0.064 \\
(-1.39)\end{array}$ & $\begin{array}{l}-0.065 \\
(-1.42)\end{array}$ & $\begin{array}{l}-0.064 \\
(-1.40)\end{array}$ & $\begin{array}{l}-0.136 * * \\
(-2.26)\end{array}$ \\
\hline Front load & $\begin{array}{l}0.113^{* *} \\
(1.99)\end{array}$ & $\begin{array}{l}0.101^{*} \\
(1.79)\end{array}$ & $\begin{array}{l}0.105^{*} \\
(1.85)\end{array}$ & $\begin{array}{l}0.142^{*} \\
(1.92)\end{array}$ \\
\hline Back load & $\begin{array}{l}0.007 * * * \\
(2.76)\end{array}$ & $\begin{array}{l}0.008^{* * *} \\
(3.00)\end{array}$ & $\begin{array}{l}0.008^{* * *} \\
(2.99)\end{array}$ & $\begin{array}{l}0.014^{* * *} \\
(4.19)\end{array}$ \\
\hline $\operatorname{Ln}(\min$ invest) & $\begin{array}{l}0.162^{* *} \\
(2.43)\end{array}$ & $\begin{array}{l}0.162 * * \\
(2.42)\end{array}$ & $\begin{array}{l}0.163^{* *} \\
(2.45)\end{array}$ & $\begin{array}{l}0.242^{* * *} \\
(2.77)\end{array}$ \\
\hline $\operatorname{Turn}\left(* 10^{-3}\right)$ & $\begin{array}{l}0.009 \\
(1.60)\end{array}$ & $\begin{array}{l}0.002 \\
(0.35)\end{array}$ & $\begin{array}{l}0.005 \\
(0.80)\end{array}$ & $\begin{array}{l}0.026 * * * \\
(3.44)\end{array}$ \\
\hline Ln(size) & $\begin{array}{l}-0.014^{* * *} \\
(-3.04)\end{array}$ & $\begin{array}{l}-0.011^{* *} \\
(-2.38)\end{array}$ & $\begin{array}{l}-0.012^{* *} \\
(-2.57)\end{array}$ & $\begin{array}{l}-0.018^{* * *} \\
(-2.84)\end{array}$ \\
\hline Ln(family) & $\begin{array}{l}0.001 \\
(0.32)\end{array}$ & $\begin{array}{l}0.001 \\
(0.48)\end{array}$ & $\begin{array}{l}0.001 \\
(0.50)\end{array}$ & $\begin{array}{l}0.005 \\
(1.53)\end{array}$ \\
\hline Services & $\begin{array}{l}0.820 * * * \\
(11.10)\end{array}$ & $\begin{array}{l}0.851^{* * *} \\
(11.40)\end{array}$ & $\begin{array}{l}0.834^{* * *} \\
(11.20)\end{array}$ & $\begin{array}{l}0.647^{* * *} \\
(6.63)\end{array}$ \\
\hline Obs & 454 & 454 & 454 & 454 \\
\hline $\operatorname{Adj}-R^{2}$ & 0.1213 & 0.1453 & 0.1347 & 0.1354 \\
\hline
\end{tabular}

As in the whole sample analysis, I find that regardless of how price is measured, or the matching methodology used, investors pay a premium at sub-advised funds. In Panel A, I find that the subadvised premium is between 9 and 10\%, while in Panel B the premium is between 11 and $14 \%$. The results presented in Table 4 suggest that the sub-advised premium is not the result of the types of funds which tend to be sub-advised. 
In addition to comparing the price of sub-advised funds with family-advised funds in general, I also compare the price within fund families. I find 48 families that both advise their own funds and are subadvisors for other families. These 48 families manage the portfolios of 465 funds. Table 5 presents the results of the analysis on this sub-sample. Panel A of Table 5 presents descriptive statistics. Comparing these statistics with those presented in Table 2, the average price of a family-advised fund is lower in this sub-sample than in the whole sample, while the price of a sub-advised fund is higher. Panel B presents the average within-family price difference when the family is a sub-advisor versus when the family manages the fund directly. As before, sub-advised funds charge significantly more. Regardless of the price measure examined, investors pay between 29 and $51 \%$ more when the family acts as a subadvisor than when the family manages the fund directly. That investors pay more for the same management when it is offered by a family they already invest with, than when it involves investing with an additional family, suggests investors are willing to pay for the convenience offered by a subadvised fund.

Table 5. Within-firm differences. The sample is composed of the 465 funds managed by the 48 families that act as both a family-advisor and a sub-advisor. The Maximum Rate is the highest (first) advisory rate specified in the advisory contract. The Marginal Rate is the advisory rate applicable given the fund's current size. The Contract Rate is calculated by applying the advisory contract to the fund's reported year-end size and dividing this by the fund's year-end size. The Actual Rate is the dollar amount investors paid for portfolio management divided by the average fund size reported on the N-SAR. The Maximum Rate Difference is the difference between the maximum rate charged by the funds the family is a sub-advisor for and the maximum rate charge by the family's funds that the family-advises. The Marginal Rate Difference is the difference between the marginal rate charged by the funds the family is a sub-advisor for and the marginal rate charge by the family's funds that the familyadvises. The Contract Rate Difference is the difference between the contract rate charged by the funds the family is a sub-advisor for and the contract rate charge by the family's funds that the family-advises. $* * *, * *, *$ indicate significance at $1 \%, 5 \%$, and $10 \%$ respectively.

\section{Panel A: Descriptive statistics when the advisor manages own funds and serves as a sub-advisor}

\section{Obs. Mean Median Maximum 75th Percentile 25th Percentile Minimum}

\section{Family-managed}

$\begin{array}{llllllll}\text { Maximum rate (\%) } & 307 & 0.686 & 0.750 & 1.750 & 0.800 & 0.600 & 0.100 \\ \text { Marginal rate (\%) } & 307 & 0.666 & 0.720 & 1.750 & 0.800 & 0.550 & 0.100 \\ \text { Contract rate (\%) } & 307 & 0.674 & 0.740 & 1.750 & 0.800 & 0.554 & 0.100 \\ \text { Actual rate (\%) } & 303 & 0.662 & 0.714 & 1.790 & 0.836 & 0.462 & 0.071 \\ \text { Sub-advised } & & & & & & & \\ \text { Maximum rate (\%) } & 158 & 0.855 & 0.900 & 1.500 & 1.000 & 0.800 & 0.400 \\ \text { Marginal rate (\%) } & 158 & 0.844 & 0.850 & 1.500 & 1.000 & 0.800 & 0.400 \\ \text { Contract rate (\%) } & 158 & 0.849 & 0.870 & 1.500 & 1.000 & 0.800 & 0.400 \\ \text { Actual rate (\%) } & 158 & 0.885 & 0.911 & 1.734 & 1.047 & 0.769 & 0.143\end{array}$

Panel B: Average percent price increase sub-advised versus when family-advised

\begin{tabular}{lll} 
& \multicolumn{1}{c}{ Mean } & Median \\
Max rate \% difference & $0.294^{* * *}$ & $0.360^{* * *}$ \\
Marginal rate \% difference & $0.301^{* * *}$ & $0.368^{* * *}$
\end{tabular}


Panel B: Average percent price increase sub-advised versus when family-advised

\begin{tabular}{lll} 
& Mean & \multicolumn{1}{c}{ Median } \\
Contract rate \% difference & $0.299 * * *$ & $0.363 * * *$ \\
Actual rate \% difference & $0.506 * * *$ & $0.469 * * *$
\end{tabular}

\section{Alternative explanations}

Alternative explanations for the observed sub-advised premium are the large family effects mentioned earlier, how funds are sold to the public, cross-fee subsidization, 401k plan limitations, and pricing complexity. That is, the observed sub-advised premium could be attributed to sub-advised funds being concentrated in larger families, where the value of intra-family trading is greater and the potential search costs associated with finding one of the family's funds are lower. However, I include the number of funds in the family to control for these types of large family effects. Additionally, these large family effects imply that all of the funds in the family, rather than just the sub-advised funds, would charge more for portfolio management. Similarly, the channels through which funds are distributed to the public would suggest that all the funds in a family-not just the sub-advised funds-could charge more for portfolio management. Del Guercio and Reuter (forthcoming) find that families tend to only offer funds through a single distribution channel, either directly to investors or through a broker. Specifically they find that only $3.3 \%$ of families offer funds through both channels. They argue that families specialize, servicing either performance sensitive investors (direct distribution) or investors willing to pay for financial advice (broker distribution). Therefore, sub-advised funds may be concentrated in families that are distributed through brokers, which tend to charge more because of the financial advice offered.

Both large family effects and distribution channels potentially explain the sub-advised premium by the types of families in which sub-advised funds are concentrated. To examine whether the sub-advised premium results from the types of families that tend to hire sub-advisors, I limit my analysis only to funds in families that contain at least one sub-advised fund. Table 6 presents evidence that contrary to both the large family effects and distribution channel explanations, even within families that employ a sub-advisor, sub-advised funds charge between 20 and $28 \%$ more than the family advised funds within the sample.

Table 6. The price of portfolio management: only families that use a sub-advisors. The sample is composed of 534 actively managed equity funds that are part of a family that employees a sub-advisor to run at least one of their funds. The Maximum Rate is the highest (first) advisory rate specified in the advisory contract. The Marginal Rate is the advisory rate applicable given the fund's current size. The Contract Rate is calculated by applying the advisory contract to the fund's reported year-end size and dividing this by the fund's year-end size. The Actual Rate is the dollar amount investors paid for portfolio management divided by the average fund size reported on the N-SAR. Sub-Advised is an indicator variable set to one if the fund is managed by a sub-advisor and zero if the fund is run by its family. Aggressive is an indicator variable that takes the value of one if the fund follows an aggressive investment strategy, aggressive growth or aggressive capital appreciation and zero otherwise. DRAC is an indicator variable that takes the value of one if the advisory contract specifies a declining advisory rate and is zero otherwise. Family Funds is the number of funds in the family. Multi Class is an indicator variable that takes the value of one if the fund offers multiple classes of shares and the value of zero if the fund only has one share class. Front Load is an indicator variable that takes the value of one if the fund has a frontend load and zero otherwise. Back Load is an indicator variable that takes the value of one if the fund has a 
redemption fee or contingent deferred sales charge and zero otherwise. As Multi Class will be perfectly correlated with Front Load and Back Load, I orthogonalize both with respect to Multi Class. Ln (Min Invest) is the natural log of the minimum investment that the fund requires to open an account for an investor. Turn is the lesser of the fund's purchases and sales divided by average net assets. $L n$ (Size) is the natural log of the fund's total net assets. Ln (Family Size) is the natural log of all assets controlled by the fund's family. Services is the number of services required by the advisory contract. ${ }^{* * *}, * *, *$ indicate significance at $1 \%, 5 \%$, ands $10 \%$ respectively.

\section{Maximum rate Marginal rate Contract rate Actual rate}

\begin{tabular}{|c|c|c|c|c|}
\hline Intercept & $\begin{array}{l}0.670 * * * \\
(6.06)\end{array}$ & $\begin{array}{l}0.743^{* * *} \\
(6.75)\end{array}$ & $\begin{array}{l}0.723 * * * \\
(6.55)\end{array}$ & $\begin{array}{l}0.665^{* * *} \\
(4.85)\end{array}$ \\
\hline Sub-advised & $\begin{array}{l}0.139 * * * \\
(6.45)\end{array}$ & $\begin{array}{l}0.149 * * * \\
(6.93)\end{array}$ & $\begin{array}{l}0.144^{* * *} \\
(6.70)\end{array}$ & $\begin{array}{l}0.186 * * * \\
(6.95)\end{array}$ \\
\hline Aggressive & $\begin{array}{l}0.007 \\
(0.31)\end{array}$ & $\begin{array}{l}0.010 \\
(0.47)\end{array}$ & $\begin{array}{l}0.009 \\
(0.41)\end{array}$ & $\begin{array}{l}0.007 \\
(0.26)\end{array}$ \\
\hline DRAC & $\begin{array}{l}-0.069 * * * \\
(-3.23)\end{array}$ & $\begin{array}{l}-0.109 * * * \\
(-5.14)\end{array}$ & $\begin{array}{l}-0.091 * * * \\
(-4.28)\end{array}$ & $\begin{array}{l}-0.106^{* * *} \\
(-4.10)\end{array}$ \\
\hline Family funds & $\begin{array}{l}0.002 \\
(1.38)\end{array}$ & $\begin{array}{l}0.002^{*} \\
(1.77)\end{array}$ & $\begin{array}{l}0.002 \\
(1.60)\end{array}$ & $\begin{array}{l}0.005^{* * *} \\
(2.70)\end{array}$ \\
\hline Multi class & $\begin{array}{l}-0.024 \\
(-1.06)\end{array}$ & $\begin{array}{l}-0.026 \\
(-1.15)\end{array}$ & $\begin{array}{l}-0.027 \\
(-1.19)\end{array}$ & $\begin{array}{l}-0.010 \\
(-0.35)\end{array}$ \\
\hline Front load & $\begin{array}{l}-0.054 \\
(-0.90)\end{array}$ & $\begin{array}{l}-0.053 \\
(-0.89)\end{array}$ & $\begin{array}{l}-0.054 \\
(-0.91)\end{array}$ & $\begin{array}{l}-0.059 \\
(-0.78)\end{array}$ \\
\hline Back load & $\begin{array}{l}0.120 * \\
(1.73)\end{array}$ & $\begin{array}{l}0.115^{*} \\
(1.66)\end{array}$ & $\begin{array}{l}0.115^{*} \\
(1.66)\end{array}$ & $\begin{array}{l}0.073 \\
(0.83)\end{array}$ \\
\hline $\operatorname{Ln}(\min$ invest) & $\begin{array}{l}-0.001 \\
(-0.20)\end{array}$ & $\begin{array}{l}-0.001 \\
(-0.04)\end{array}$ & $\begin{array}{l}0.001 \\
(0.04)\end{array}$ & $\begin{array}{l}0.001 \\
(0.37)\end{array}$ \\
\hline Turn $\left(* 10^{-3}\right)$ & $\begin{array}{l}0.287^{* * * *} \\
(3.64)\end{array}$ & $\begin{array}{l}0.262^{* * *} \\
(3.34)\end{array}$ & $\begin{array}{l}0.285^{* * *} \\
(3.62)\end{array}$ & $\begin{array}{l}0.488^{* * *} \\
(5.00)\end{array}$ \\
\hline Ln(size) & $\begin{array}{l}0.006 \\
(0.96)\end{array}$ & $\begin{array}{l}-0.003 \\
(-0.46)\end{array}$ & $\begin{array}{l}-0.001 \\
(-0.01)\end{array}$ & $\begin{array}{l}0.030 * * * \\
(3.66)\end{array}$ \\
\hline Ln(family) & $\begin{array}{l}-0.008 \\
(-1.03)\end{array}$ & $\begin{array}{l}-0.007 \\
(-0.89)\end{array}$ & $\begin{array}{l}-0.007 \\
(-0.96)\end{array}$ & $\begin{array}{l}-0.032^{* * *} \\
(-3.39)\end{array}$ \\
\hline Services & $\begin{array}{l}0.009 * * * \\
(2.73)\end{array}$ & $\begin{array}{l}0.009 * * * \\
(2.77)\end{array}$ & $\begin{array}{l}0.009 * * \\
(2.83)\end{array}$ & $\begin{array}{l}0.016^{* * *} \\
(3.93)\end{array}$ \\
\hline Obs & 534 & 534 & 534 & 529 \\
\hline $\operatorname{Adj}-R^{2}$ & 0.1304 & 0.1641 & 0.150 & 0.1880 \\
\hline
\end{tabular}

Additionally, in un-tabulated tests, I replace the sub-advised fund indicator with an indicator for membership in a family that employees a sub-advisor, which takes the value of one for any fund belonging to a family that employs a sub-advisor. If large family effects or distribution channels are 
responsible for the sub-advised premium, then this family sub-advised indicator should be positive and significant. However, I find no evidence of a positive and significant relation between the family subadvised indicator and the price of portfolio management. Interestingly, I do find a significantly negative relation between the family sub-advised indicator and the maximum rate and actual rate. These results suggest that the sub-advised premium is not the result of large family effects or distribution channels. Lastly, in unreported tests I find that family-advised funds within families that employ a sub-advisor actually charge less than other family-advised funds. This also argues against large family effects and distribution channels as an explanation for the sub-advised premium.

I separate large family effects from convenience; however, if one considers large family effects as part of the convenience offered by a sub-advised fund, then this discussion can be viewed as arguing that convenience goes beyond just large family effects.

Cross-fee subsidization implies that while the advisory fee is the stated means of paying for portfolio management, funds could charge a lower advisory rate and increase other fees to make up for the lost revenues. The sub-advised premium could result from family-advised funds engaging in cross-fee subsidization. In un-tabulated tests comparing the expense ratios of family-advised funds to those of sub-advised funds, I find that sub-advised funds have higher expense ratios than family-advised funds. This suggests that cross-fee subsidization is not able to explain the sub-advised premium.

It also seems unlikely that the sub-advised premium is due to $401 \mathrm{k}$ plan limitations. Potentially, the limited investment options offered by $401 \mathrm{k}$ plans may allow funds to charge a premium. However, Elton et al. (2006) find that plan sponsors generally select funds with lower expense ratios and higher past performance for inclusion in $401 \mathrm{k}$ plans. Thus, it seems unlikely that plan sponsors would select a sub-advised fund given their tendency to underperform, their higher expense ratios, and the necessity of splitting the revenue generated from the fund with the sub-advisor.

Finally, price complexity is an improbable explanation for the sub-advised premium. Carlin (2009) shows how firms can increase the complexity of their pricing to prevent consumers from easily comparing prices. However, the uniformity of the pricing convention in the mutual fund industry suggests that families are not using pricing complexity to charge more. Additionally, in unreported tests I compare the combined effect of loads and expense ratios. I find evidence that sub-advised funds continue to charge more than family-advised funds, which suggests that pricing complexity is not able to explain the sub-advised premium.

\section{Implications of convenience}

Berk and Green (2004) assert that capital flows flock to mutual funds with superior performance because investors interpret prior performance as a signal of management ability. Therefore, if investors select sub-advised funds for their convenience and not management ability, we would expect that flows to sub-advised funds will be less responsive to prior performance than flows to familyadvised funds, which are selected primarily for portfolio management.

I explore this implication of convenience by comparing sub-advised funds' flow sensitivity to superior performance to the flow sensitivity of family-advised funds. I first match my sample to the CRSP Survivor-Bias-Free US Mutual Fund Database (hereafter CRSP). $\underline{16}$ I then follow the same matching 
procedures used to create the two matched samples examined in Table 4. The matching methodologies result in two different samples, both comprising 244 funds split evenly between subadvised and family-advised funds. $\underline{17}$

The CRSP database provides each fund's monthly return, size, expense ratio, family affiliation, and the date the fund was first offered. I follow Sirri and Tufano (1998) in calculating flows and in using a piecewise linear analysis to examine the performance-flow relation. $\underline{18}$ Each month funds are ranked according to their performance over the prior month. The fund with the worst performance receives a ranking of 0 , while the best performing fund receives a ranking of 1 . To allow for the asymmetric performance-flow relation, this ranking is spread across two performance groups: performance and high performance. The breakpoint is set at 0.8. $\underline{19}$ What this implies is that a fund with a performance ranking of 0.9 , the 90 th percentile performer, would have a performance score of 0.8 , and a high performance score of $0.1 . \underline{20}$ In addition to allowing for the non-linear performance-flow relation, I also control for the flows to the fund in the month prior, the fund's expense ratio, age, size, and family size.

Table 7 presents the results of this analysis. Column 1, the style size matched sample, finds that flows to family-advised funds are highly sensitive to high performance, while sub- advised funds' flow sensitivity to high performance is only $36 \%$ of the family-advised funds' flow sensitivity to high performance. Column 2, the sub-advised probability matched sample finds that while family-advised funds' flows are highly sensitive to high performance, sub-advised funds' flows are relatively indifferent to performance; sub-advised funds' sensitivity to high performance is only $24 \%$ of the sensitivity of family advised funds. While not a direct test that sub-advised funds are selected because they are convenient, the results are consistent with investors choosing sub-advised funds for reasons other than beliefs about management ability. $\underline{\underline{21}}$ This suggests that mutual fund investors' portfolios are comprised of two types of funds. The first are "skill" funds; these are the funds that the investor selects based on beliefs about portfolio management ability. The second are the "convenient" funds; these are the funds that investors select because they are relatively convenient to the "skill" funds the investor has chosen.

Table 7. The performance flow relation. This table presents the results of my Fama-MacBeth analysis of the relation between monthly performance and monthly net flow between 2000 and 2007. The sample is composed of a 244 fund. The 122 sub-advised funds and 122 family-advised style and size matched funds. The dependent

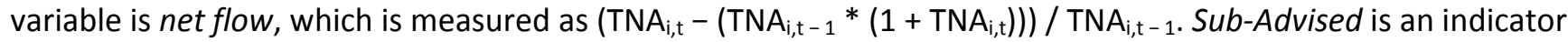
variable set to one if the fund is managed by a sub-advisor and zero if the fund is run by its family. Each month, I rank each funds prior month's performance. Performance is defined as the Min (Rank, 0.8). High-performance is defined as Max (Rank - Low Performance, 0). Sub-Advised * Performance is the interaction between a subadvised indicator and Performance. Sub-Advised * High Per is the interaction between a sub-advised indicator and High Performance. Lagged Flow is the fund's flow for the month prior. Exp is the fund's CRSP reported expense ratio. $\operatorname{Ln}(\mathrm{Age})$ is the log of the number of months that the fund has been offered. Sub-Advised is an indicator variable set to one if the fund is managed by a sub-advisor and zero if the fund is run by its family. $\operatorname{Ln}($ Size) is the log of the fund's prior month's TNA. Ln(Fam Size) is the log of the fund family's prior month's TNA.***,**,* indicate significance at $1 \%, 5 \%$, and $10 \%$ respectively.

\section{Style and size matched Probability matched}

Intercept
$0.044 * * *$
$0.077^{* * *}$

Performance

0.004

$0.046 * * *$ 


\section{Style and size matched Probability matched}

(1.05)

High performance

$0.086^{* * *}$

$-0.004$

Sub-advised * performance

$(-0.87)$

Sub-advised * high per

$-0.055^{* *}$

$(-2.03)$

Lagged flow

$0.282^{* * *}$

Exp

Ln(age)

Sub-advised

$-0.450 * * *$

$(-4.59)$

$-0.011^{* * *}$

$(-10.93)$

0.004

(1.52)

$0.004^{* * *}$

Ln(size)

(6.09)

$-0.001$

$(-1.03)$

Obs

Adj-R ${ }^{2}$
33,464

0.1786
$0.161^{* * *}$

(4.25)

$-0.043 * * *$

$(-5.96)$

$-0.123 * * *$

$(-2.91)$

$0.111^{* * *}$

$-1.117^{* * *}$

$(-6.47)$

$-0.020 * * *$

$(-17.10)$

$0.020 * * *$

$0.005^{* * *}$

0.001

33,464

0.0990

\section{Conclusion}

In this paper I present evidence that investors value convenience and that convenience plays a part in the selection of some funds. I find that on average investors pay a premium of $7-13 \%$ to invest in a sub-advised fund. I also find that within families that are employed as sub-advisors by other families and, advise their own funds the funds which are sub-advised charge $30 \%$ more than the funds the family advises directly. Within families that hire a sub-advisor I find that the sub-advised funds charge between $18-20 \%$ more than the family advised funds. These results all suggest that investors value convenience and are willing to pay for it.

I next examine the role of convenience in fund selection. If sub-advised funds are able to charge a premium because of convenience, then it suggests that investors select sub-advised funds for their convenience while they select family-managed funds for portfolio management. This suggests that the flows to sub-advised funds will be less responsive to prior performance, as investors believe that prior returns signal portfolio management ability. Consistent with this rationale I find that sub-advised funds' flows are relatively indifferent to prior performance. 
These findings suggest that investors do not select funds independently and are consistent with the notion that investors' portfolios are comprised of two types of funds: skilled funds, which are selected based on investor beliefs about the ability of the portfolio manager, and convenience funds, which are selected because they are convenient to the skilled funds. This behavior is potentially harmful to investors, as it increases the risk of their total investment portfolio, while decreasing its expected return (Elton et al. (2007) and Siggelkow (2003)).

\section{References}

Baumol, W.J., Goldfeld, S.M., Gordon, L.A., Koehn, M.F., 1990. The economics of mutual fund markets: competition versus regulation. Kluwer Academic Publishers, Boston.

Berk, J.B., Green, R.C., 2004. "Mutual fund flows and performance in rational markets." J. Polit. Econ. $112,1269-1295$.

Carlin, B., 2009. "Strategic price complexity in retail financial markets." J. Financ. Econ. 91, 278-287.

Cashman, G.D., Deli, D.N., 2009. “Locating decision rights: evidence from the mutual fund industry." J. Financ. Mark. 12, 645-671.

Cashman, G.D., 2010. "Pay-performance sensitivity and firm size: insights from the mutual fund industry." J. Corp. Finance 16, 400-412.

Cashman, G.D., Deli, D.N., Nardari, F., Villupuram, S.V., forthcoming. "Investors do respond to poor mutual fund performance: evidence from inflows and outflows." The Financial Review. http://dx.doi.org/10.2139/ssrn.945296.

Chen, J., Hong, H., Kubik, J.D., 2011. “Outsourcing mutual fund management: firm boundaries, incentives, and performance." Working paper.

Coles, J., Suay, J., Woodbury, D., 2000. "Fund advisor compensation in closed-end funds." J. Finance 55, 1385-1414.

Del Guercio, D., Reuter, J., Tkac, P.A., forthcoming. “Demand for financial advice, broker incentives, and mutual fund market segmentation." The Financial Review. http://dx.doi.org/10.2139/ssrn.1361710.

Deli, D.N., 2002. “Mutual fund advisory contracts: an empirical investigation.” J. Finance 57, 109-133.

Elton, E.J., Gruber, M.J., Blake, C.R., 2006. "The adequacy of investment choices offered by 401(k) plans." J. Public Econ. 90, 1299-1314.

Elton, E.J., Gruber, M.J., Green, T.C., 2007. "The impact of mutual fund family membership on investor risk." J. Financ. Quant. Anal. 42, 257-278.

Fredman, A.J., Wiler, R., 1998. How Mutual Funds Work. Prentice Hall, Inc., New York. 
Gallaher, S., Kaniel, R., Starks, L., 2006. “Madison avenue meets Wall Street: mutual fund families, competition, and advertising." Working paper. University of Texas.

Khorana, A., Servaes, H., 2004. "Conflicts of interest and competition in the mutual fund industry." Working paper.

Massa, M., 2003. "How do family strategies affect fund performance? When performancemaximization is not the only game in town." J. Financ. Econ. 67, 249-304.

Nanda, V., Wang, Z.J., Zheng, L., 2004. "Family values and the star phenomenon: strategies of mutual fund families." Rev. Financ. Stud. 17, 667-698.

Schifrin, M., 1994. "Fund malls." Forbes 153, 234-235 (June).

Siggelkow, N., 2003. "Why focus? A study of intra-industry focus effects." J. Ind. Econ. 51, 121-150.

Sirri, E.R., Tufano, P., 1998. "Costly search and mutual fund flows." J. Finance 53, 1589-1622.

Warner, J.B., Wu, J.S., 2011. "Why do mutual fund advisory contracts change? Performance, growth, and spillover effects." J. Finance 66, 271-306.

I would like to thank Stuart L. Gillan, Brett Myers and seminar participants at Texas Tech and Rice University for their helpful comments.

${ }^{1} \mathrm{I}$ explore alternative explanations for the premium in Section 5.

${ }^{2}$ Investing through a fund supermarket potentially allow investor to follow a multiple family strategy as conveniently as limiting their investments to a single family, which potentially weakens the importance of family boundaries. However, investors are often still advised to invest with a single family; for example, the American Association of Individual Investors http://www.aaii.com/investing/article/mutual-funds-faqs. Additionally, investors could limit themselves to only the family-advised funds within the family. However, both of these would bias me against finding that sub-advised funds charge a premium.

${ }^{3}$ While the evidence I present is indirect it does provide an interesting line of inquiry that likely requires transaction level data.

${ }^{4}$ Moreover, by opening accounts in multiple families that specialize in the various strategies desired, an investor could avoid both the premium charged by sub-advised funds, and their relative underperformance.

${ }^{5} \mathrm{~A}$ fund is considered to be outsourced if any advisor is not affiliated with the fund family. This definition includes team-managed funds, which are excluded from Cashman and Deli's (2009) definition of sub-advised. 
${ }^{6}$ Specifically, these prior studies examine the marginal compensation rate, which is analogous to my marginal rate described in Section 3.2.

${ }^{7}$ The N-SAR filing specifically asks if the following services are required: (1) occupancy and office rental; (2) clerical and bookkeeping services; (3) accounting services; (4) services of independent audits; (5) services of outside counsel; (6) registration and filing rates; (7) stationery, supplies, and printing; (8) salaries and compensation of interested directors; (9) salaries and compensation of disinterested directors; (10) salaries and compensation of officers who are not directors; (11) reports to shareholders; (12) determination of offering and redemption prices; (13) trading department; (14) prospectus preparation and printing; and (15) other services.

${ }^{8}$ Cashman and Deli (2009) provide a detailed exposition regarding the issues associated with creating a panel when using ADV filings. The ADV filings used in this study were collected in January 2003.

${ }^{9}$ The $14 \%$ sub-advised is less than the $27 \%$ outsourced reported by Chen et al. (2011). This is because outsourced funds include both sub-advised funds and team managed funds.

10 The marginal rate is analogous to the Coles et al. (2000) and Deli (2002) marginal compensation rate. However, I take the viewpoint of the other contracting party, the investor, and view this as a cost.

${ }^{11}$ I receive qualitatively similar results using the fiscal-year end size, instead of the average size.

${ }^{12}$ As all multi-share class funds will have a front- and back-end load, the multiple share class indicator is orthogonal to the front- and back-end load indicator.

${ }^{13}$ Intra-family trading refers to the ability of investors to trade funds within a family without incurring the normal fees associated with redeeming and purchasing shares.

14 The changing significance of my declining-rate advisory contract indicator is consistent with the implications of Cashman (2010).

${ }^{15}$ Cashman and Deli (2009) Model 2 Table 6: $\mathrm{P}($ Sub-Advised) $=f$ (whether the fund invests for capital gains, whether the fund invests in derivatives or restricted securities, turnover, the number of funds managed by the family, the family's assets under management, the family's capital gain concentration, and the interaction of the capital gains indicator and the family's capital gains concentration).

${ }^{16}$ I follow the matching methodology used by Cashman (2010) and Cashman et al. (forthcoming).

${ }^{17}$ The first sample matches each sub-advised fund to the family-advised fund that is closest in size and follows the same investment strategy. The second sample matches each sub-advised fund to the family-advised fund which has the closest estimated probability of being sub-advised. The samples are composed exclusively of funds I was able to match to CRSP. 
${ }^{18}$ Flows are calculated as $\left\{\right.$ TNA $_{t}-\left[\right.$ TNA $_{t-1} *(1+$ Return $\left.\left.t)\right]\right\} / T N A_{t-1}$.

${ }^{19}$ I have run this analysis using 0.66 instead of 0.8 ; the results are qualitatively similar.

${ }^{20} \mathrm{~A}$ fund with a raw ranking of 0.5 , the median performer, would have a Performance score of 0.5 , and a High Performance score of 0.0 .

${ }^{21}$ Investors choosing a fund for convenience may also be less concerned with the expense ratio. In unreported tests I include a sub-advised *expense ratio interaction and find no evidence that investors respond differently to expense ratios at sub-advised funds. 